кандидат педагогічних наук, доцент

(Херсонський державний університет) annabelan77.ab@gmail.com

ORCID: 0000-0002-6032-2779

\title{
ФІЛОСОФІЯ ДЛЯ ДІТЕЙ В. О. СУХОМЛИНСЬКОГО В СВІТОВОМУ ОСВІТНЬОМУ ПРPOCTOPI
}

У статті розглядається філософія для дітей В. О. Сухомлинського як складова морально-етичного виховання особистості, обгрунтовано пріоритетність значення розвитку мислення дитини, формування

ї̈ світогляду крізь призму філософського знання засобами художнього слова в прочесі діалогічної взаємодї з педагогом. На основі наукової та літературної спадщини В. О. Сухомлинського показано його новаторство у проблемі розвитку духовності та інтелектуального потенціалу особистості, встановлено взаємозв'язок поглядів педагога із подібними ідеями М. Ліпмана (США), охарактеризовано особливості впровадження філософії для дітей у вітчизняний та світовий освітній nростір.

Ключові слова: філософія для дітей, мислення, духовність, гуманізм, особистість, література для дітей, освітній простір.

Постановка проблеми. Домінантною тенденцією функціонування суспільства XXI століття $\epsilon$ постійні трансформації у всіх сферах: економічній, політичній, громадсько-культурній тощо. Сучасна людина знаходиться у вирі перманентних змін, які торкаються усіх аспектів іiі життєдіяльності, що призводить до зміщень іiі особистих пріоритетів і цінностей, вимагає прийняття непростих щоденних рішень, як побутових, так і екзистенційних, які несуть у собі пролонговані наслідки для їі подальшої долі. У такому контексті великого значення набуває уміння особистості адаптуватися до швидкозмінних життєвих обставин, сприймати нестабільність - як можливість до саморозвитку і самовдосконалення, розвивати здатність до самовизначення в наявних суспільних умовах у відповідності як до шкали загальнолюдських цінностей, так і власних аксіологічних пріоритетів. Аксіоматичним є твердження, що важливу роль у формуванні таких умінь людини відіграє освіта, основним завданням якої $є$ підготовка дитини до наявних суспільних реалій шляхом надання їй необхідних життєвих компетентностей та стратегій саморозвитку. Основними завданнями освіти сьогодні $€$ розвиток творчого потенціалу особистості, формування навичок самостійного пізнання дійсності, навчання критичного осмислення будь-яких життєвих ситуацій і проблем. Вирішенню цих завдань нині сприяє розробка низки програм, методик, практик, які спрямовані на формування самодостатньої, цілісної, творчої, думаючої людини, гідного свідомого громадянина своєї держави, високоморального члена суспільства. В контексті нашої наукової розвідки акцентуємо на одній із таких програм під назвою "Філософія для дітей", яка має понад сорокарічний досвід поширення у світовому освітньому просторі, викликаючи науковий інтерес сучасних вітчизняних дослідників.

Аналіз останніх досліджень. У працях Н. С. Юліної "Философия для детей" (1993), О. В. Сухомлинської "Філософія для дітей як педагогічна проблема" (2002), Г. П. Іванчук "Зміст і завдання програми Метью Ліпмана "Філософія для дітей" (2003), Н. Адаменко "Спільнота дослідників" М. Ліпмана : філософські запитування обговорення, аргументації та контраргументації вустами дітей" (2011), О.В.Сухомлинської "Філософія для дітей в етичній спадщині В. О. Сухомлинського" (2012), С. О. Ганаби "Навчати мисленню": епістеміологічний проект Метью Ліпмана" (2013) та інших проаналізовано зміст і сутність понять "філософія для дітей", "критичне мислення", "рефлексивне мислення" тощо, розкрито основні положення і шляхи реалізації цієї програми в навчально-виховному процесі, особливості організації "співтовариства дослідників" у проблемно-пошуковій діяльності суб'єктів навчальної взаємодії (учитель-учень, учень-учень) 3 метою креативного розгляду та осмислення отриманих знань. Загальний зміст цих наукових розвідок - це розгляд евристичного потенціалу програми "Філософія для дітей". Визначаючи сутність філософії для дітей, як освітнього напряму, С. О. Ганаба підкреслює: "В основі курсу "Філософія для дітей" лежать проблемно-діяльнісні методи отримання знань, які спрямовані на розвиток самостійного критичного осмислення проблем, пробудження творчого потенціалу учасників навчальної взаємодії. Увага фокусувалася не на запам'ятовуванні інформації, а на ііі "творенні філософією", яка передбачає використання зусиль з боку інтелекту, розв'язання проблем, пов’язаних з повсякденним життям учасників освітньої взаємодії... В межах навчальної програми "Філософія для дітей" відбувається відхід від традиційної інформаційної моделі на користь рефлексивної, яка акцентує увагу на розвитку мислення, використанні внутрішнього, емоційного потенціалу учасників освітньої взаємодії" [1: 5]. 
Підтверджуючи існування достатньої кількості методик і технологій упровадження в освіту такої філософії, О.В.Сухомлинська зазначає: "...Філософія для дітей - це основні питання філософії (як гносеології, так і онтології), поставлені у художньо-пізнавальних текстах для дітей професійними педагогами... Нині філософія для дітей - це жива, затребувана педагогіка і практика, яка включає школи й дошкільні заклади, учених-дослідників і вчителів" [2: 7]. Відтак, науковці констатують та аргументують доцільність уведення основ філософських знань у навчально-виховний процес, підкреслюючи їх запитальний характер, що визначає стиль міркування, вміння конструювати гіпотези та формулювати судження, що в результаті сприятиме розвитку мислення дитини в якості навички, що має природну можливість до вдосконалення. Варто відзначити, що у контексті розгляду наукової проблеми філософії для дітей дослідники значну увагу приділяють поняттю "критичне мислення", розглядаючи історію його розвитку в історичній ретроспективі, висвітлюючи підходи зарубіжних і вітчизняних учених до трактування його сутності (С. О. Ганаба), а також відзначаючи, що саме такий тип мислення $\epsilon$ передумовою успішної діяльності особистості у сучасному суспільстві. Навчання критичному мисленню, яке трактується як рефлексивне мислення, "мислення про мислення", що сфокусоване на культивуванні прагнення до пошуку власних відповідей, свідомого міркування, творчих інтенцій, що лежить в основі програми "Філософія для дітей", може стати однією із відповідей освітньої системи на запити сучасності щодо формування нової людини ХХІ століття, освіченої, моральної, гнучкої, здатної оріснтуватися у безмежному інформаційному просторі, навчатися і перенавчатися.

О. В. Сухомлинська стверджує : "Вона (філософія для дітей - Г. Б.) спрямована на формування рефлексивного, творчого і критичного мислення, усвідомленого прийняття моральних правил і норм, взірців духовної культури, вміння слухати і чути іншого, спілкуватися з іншими, передбачає розвиток мовлення. Усе перераховане вище знаходимо в педагогічній спадщині Сухомлинського. I не просто відшукуємо - цими темами і сюжетами наповнено сторінки його творів, особливо ті, що стосуються морально-етичного виховання дітей" [2: 7]. Отже, метою статті є показати особливості функціонування філософії для дітей В. О. Сухомлинського у світовому освітньому просторі.

Виклад основного матеріалу. Педагогічна система В. О.Сухомлинського охоплює майже усі сторони такого складного і багатогранного поняття, як навчально-виховний процес, спрямована на його організацію 3 максимальним урахуванням інтересів дитини, оскільки цінність іiі особистості, сформованість ії якостей, світоглядних позицій впливатиме на майбутнє усього людства. Виходячи 3 розуміння того, що кожна особистість $є$ унікальною та неповторною і саме постать дитини є центром навчально-виховного процесу, педагог підкреслював, що за створення відповідних умов виховного впливу кожна дитина має усі можливості стати інтелектуальною, мислячою, високоморальною людиною, здатною на правильний життєвий вибір. Аналіз змісту праць В. О. Сухомлинського щодо теорії і практики організації навчально-виховного процесу засвідчує його глибоке переконання, що тонкий духовний світ школяра формується із розвитком уміння мислити, висловлювати свої думки, оцінювати життєві явища, поведінку людей i, передусім, власні вчинки крізь призму загальнолюдських цінностей: добра, любові, довіри, поваги.

Особливу увагу у контексті нашої проблеми викликають твори педагога для дітей, які, власне, і $є$ інструментом мудрого, прихованого впливу на формування внутрішнього світу особистості. Художні мініатюри В. О. Сухомлинського, призначені для дитячого читання, посідають особливе місце у його творчому доробку, оскільки є майстерними зразками художньої літератури для дітей, які водночас несуть надзвичайний виховний і повчальний потенціал. Їх призначення - філософське пізнання дійсності, осмислення дитиною реалій життя, формування аксіологічних орієнтирів та визначення власних світоглядних позицій особистості. Народжені у процесі багаторічної практичної педагогічної взаємодії, ці оповідання, казки, притчі, новели, легенди були невід'ємною частиною системи роботи Павлиської школи в аспекті морального, етичного виховання дітей. Аналіз змісту праць В. О. Сухомлинського засвідчує його глибоке переконання, що формування особистісної моралі школяра є провідною, визначальною метою навчально-виховного процесу у закладах освіти. Визначну роль у ії реалізації В. О. Сухомлинський відводить вихователю, як мудрому авторитетному керівникові, що залучає дитину до світу найвищих людських цінностей, спонукає до морального самоствердження внаслідок щоденної праці розуму і серця, прикладання вольових зусиль у прийнятті життєвих рішень та їх здійснення. Праці "Як виховати справжню людину (Етика комуністичного виховання)" (1975) (посібник для вчителів) і "Хрестоматія з етики" (1990) (оповідання для дітей) стали квінтесенцією ідей педагога щодо здійснення морального виховання зростаючої особистості, охоплюючи водночас усі аспекти свідомого осмисленого пізнання дитиною життєвих реалій. "Більшість творів "Хрестоматії 3 етики" ми й розглядаємо як філософію для дітей. Це оповідання, казки, легенди, притчі, новели, що розкривають суть пізнання світу через моральність. Використавши художні образи, В. О. Сухомлинський розглянув проблеми формування моральної свідомості дітей, моральних стосунків, моральної діяльності, моральних цінностей", - наголошує О.В.Сухомлинська у праці "Філософія для дітей в етичній спадщині В. О. Сухомлинського", підтверджуючи наявність елементів впровадження філософського знання в 
системі практичної освітньої роботи Павлиської школи [3: 56]. Продовжимо цю думку цитатою з іншої статті дослідниці "В. О. Сухомлинський і моральне виховання: трансформація педагогічних цінностей", в якій стосовно змісту "Хрестоматії з етики" зазначено, що у цій книзі "... подано морально-етичні категорії добра і зла, краси, любові і ненависті на рівні дитячого світовідчуття та світосприйняття, ...висунуто моральні імперативи "співчуття", "співпереживання", як компоненти гуманної поведінки особистості... Звернення до внутрішнього світу особистості школяра стало початком розвитку гуманістичної моральної традиції та гуманістичного ідеалу в їх радянському варіанті" [4: 67]. Відтак, дослідження сучасних вчених на основі грунтовного аналізу творчого доробку В. О. Сухомлинського засвідчують не тільки звернення педагога до основ філософських понять і категорій з метою їх практичного впровадження в навчально-виховний процес, а й той факт, що саме він першим у радянській педагогічній науці звернувся до морально-етичної, і в цьому контексті-філософської, проблематики (1961), виокремив моральне виховання як основу формування самодостатньої, цілісної, мислячої особистості, як стрижневу проблему виховного процесу, розробив форми і методи формування моральності (художні мініатюри для дітей із вираженим філософським змістом, методичні поради для вчителів щодо роботи із цими творами, розробка загальних положень щодо розвитку мислення дитини, формування іiі світоглядних позицій), що охоплюють усі аспекти життедіяльності дитини та спрямовані на об’єктивне емоційне пізнання нею дійсності, сутності людських стосунків та визначення власної світоглядної парадигми. Такі твердження сучасників підкреслюють той факт, що ідеї та погляди В. О. Сухомлинського як педагога-теоретика та педагога-практика були "революційними" в еволюційному плині педагогічної науки 60 -х років XX століття. Постановка цієї проблеми була продиктована передусім соціальними запитами в умовах "відлиги" означеного часового проміжку та часткової демократизації в усіх галузях життєдіяльності радянського суспільства, коли поняття "духовність", "моральність" особистості набували особливого звучання. Відштовхуючись від потреб часу та суспільних вимог, В. О. Сухомлинський як педагог-практик, чиї наукові міркування отримували неоціненне практичне підтвердження в діяльності Павлиської середньої школи, із особистісних переконань свідомо звернувся до розробки проблем морального виховання як основи розвитку духовного світу дитини і як пріоритетного завдання виховання дітей [4: 66].

У контексті нашої проблеми знаковим моментом $є$ період появи цих ідей педагога $-60-70$-ті роки XX століття, адже саме в цей час суголосні думки про розвиток мислення дитини, про важливість проблемно-аналітичного пізнання явищ дійсності, про формування цілісної самодостатньої особистості із чіткими уявленнями про загальнолюдські цінності виникають в світовому освітньому просторі. Так, зокрема, набувають популярності дослідження зарубіжного сучасника В. О. Сухомлинського, професора філософії Колумбійського університету Метью Ліпмана (США), присвячені проблемі необхідності впровадження основ філософії у освітній процес із метою розвитку критичного мислення підростаючої особистості. "Метью Ліпман - знаний теоретик освіти.. Він $\epsilon$ автором "рефлексивної" моделі освіти, у якій фокус навчальної діяльності спрямовується не на засвоєння певної інформації, а на осмислення внутрішніх сенсів та характеристик предметів та явищ, які досліджуються", - зазначає С. Ганаба [1: 2]. На основі праць американського вченого дослідниця обгрунтовує концептуальні засади розвитку критичного мислення у сфері освіти та виокремлює сутнісні характеристики критичного мислення, визначені М. Ліпманом наприкінці 60-х pp. XX століття: майстерність (уміння мислити), відповідальність (зв'язок між критично мислячою особистістю та спільнотою, з якою вона спілкується), формулювання самостійних суджень (за відсутності жорстких алгоритмів та стереотипів), самокорекція власних суджень (з метою їх виправлення чи вдосконалення). Вона підкреслює, що практична реалізація ідей М. Ліпмана відбулася у 70-х роках ХХ століття в США завдяки розробці під його керівництвом програми викладання філософії у школі під назвою "Філософія для дітей", яка згодом набула популярності в багатьох країнах світу. "Філософія для дітей" має на меті не стільки презентувати світовий розвиток філософської думки, скільки запозичити ії запитальний характер, стиль міркування, визнання поліваріантності відповідей, вміння конструювати гіпотези, формулювати судження тощо. Лозунг даної програми : "Міркуванню треба навчати", - наголошує С. Ганаба [1: 4-5]. Відтак, американський учений акцентує на важливості діалогу в навчальному процесі, який перетворює педагога і учнів у "спільноту дослідників", які у живому емоційному спілкуванні ставлять запитання, здобувають знання, формують власні світоглядні позиції, відверто висловлюють свої міркування, що спонукають до екзистенційних пошуків сенсу життя, місця і ролі людини в суспільстві, ії призначення тощо.

У працях сучасних дослідників О. В. Сухомлинської "Філософія для дітей в етичній спадщині В. О. Сухомлинського", Л. В. Пікуль "Уроки мислення" В. Сухомлинського і "Філософія для дітей" Метью Ліпмана" констатується змістовий взаємозв'язок поглядів американського й українського педагогів щодо пізнання дитиною світу крізь призму філософських знань. О. В. Сухомлинська узагальнює концепцію навчання дітей філософії М. Ліпмана, виокремлюючи такі ії складові: тексти для дитячого читання, у яких закладено в прихованій або очевидній формі одне або кілька філософських питань; навчально-методична література для вчителів, у яких викладена методика роботи педагога із 
цими текстами; узагальнюючі теоретичні роботи, у яких аналізується досвід, досягнення і вади навчання філософії в школі; сократичний діалог між учителем і учнем як безпосередній метод навчання [3: 54]. Дослідниця підкреслює науковий і практичний потенціал концепції М. Ліпмана, зазначаючи : "Цей досвід викликає в нас великий інтерес, бо в Україні є свої напрацювання в аспекті філософського пізнання й опанування світу дитиною. Маю на увазі педагогічну (зокрема етичну) спадщину В. О. Сухомлинського, написані ним оповідання для дітей, розроблену систему занять, впроваджену в практику середньої школи, якою він керував" [3: 54]. Дійсно, читаючи тексти для дитячого читання, написані В. О. Сухомлинським і М. Ліпманом, методичні рекомендації для вчителів, розроблені педагогами, знаходимо спільні погляди і міркування щодо освітньої практики, організації навчальновиховного процесу, загального розвитку особистості дитини. Головною відмінністю стало впровадження висловлених українським і американським вченими думок у практику освіти: В. О. Сухомлинський працював у задушливій атмосфері офіційної радянської педагогіки, змушений відстоювати і боротися за кожну новаторську ідею, "Хрестоматія з етики" була надрукована вже після його смерті; розробки ж М. Ліпмана отримували урядову підтримку, він сміливо експериментував, обгрунтовуючи доцільність своїх ідей. У статті Н. Адаменко наведено конкретні факти: М. Ліпман працював у колі вчениходнодумців (В. Бейєр, Г. Метьюс, Ф. Осканян, М. Прітчард, Л. Спліттер, А. Шарп), вільно друкував теоретичні статті щодо філософських практик, супровідні матеріали для вчителів; було створено "Інститут з розвитку для філософії дітей"; було проведено експериментальні дослідження за рахунок Бюро з вивчення, планування та оцінювання Департаменту освіти штату Нью-Джерсі (1970, 1975, 1976, 1979, 1980, 1981 рр.); до кінця 1970-х рр. у США понад 5 тис. класів навчалися за програмою "Філософія для дітей", яка отримала високу оцінку комісій з питань освіти ООН, ЮНЕСКО [5: 279-280]. Отже, ідеї щодо концептуальних змін в практиці освіти, висловлені в хрономежах 60-70-х років ХХ в радянській Україні та США мали різну динаміку розвитку, зумовлену особливостями соціально-історичного та економіко-політичного устрою в цих країнах. Поява цих змін в освітніх системах світу в означений період була зумовлена прискореним темпом науково-технічного прогресу, появою i швидким розповсюдженням нових технологій, а відтак і новими запитами суспільства щодо особистісних якостей людини. Нові професії вимагали високого інтелекту, здатності засвоювати велику кількість інформації, уміння приймати оперативні й адекватні рішення. Ці фактори поставили перед освітою непрості завдання: постійне оновлення змісту навчальних дисциплін, створення умов для високого рівня загального розвитку дитини, розвиток критичного мислення, комунікабельності, уміння приймати самостійні відповідальні рішення, навчатися і перенавчатися. Зрозуміло, що у США розробка i впровадження програми "Філософія для дітей", яка була спрямована на вирішення цих завдань, отримувала підтримку на всіх рівнях. В той же час відносно "закрита" політична система СРСР не могла не реагувати на науково-технічний прогрес в країні, i радянська економіка також потребувала висококваліфікованих професіоналів. Офіційна педагогіка була перед важким вибором: між важливістю утримувати ідеологічні позиції серед населення та необхідністю розвитку його інтелектуального потенціалу, що становило імпліцитну загрозу стабільності урядових структур. У такій ситуації ідеї В. О. Сухомлинського зустрічали опір на всіх рівнях, проте глибоке переконання педагога-практика у важливості і доцільності запропонованих ним освітніх інновацій щодо стимулювання інтелектуального й духовного розвитку людини давало йому сили відстоювати свої думки.

Висновки. Підсумовуючи, підкреслюємо, що значимість та новаторство науково-педагогічних пошуків В. О. Сухомлинського щодо морального виховання особистості, розвитку їі мислення, почуттів, ціннісних орієнтацій та впровадження основ філософського знання у практику освітньої діяльності навчальних закладів не викликає сумнівів. Його ідеї були й залишаються каталізатором наукових відкриттів та безцінним надбанням педагогічної науки, що призвели до утворення концептуальних змін у iii розвитку як у вітчизняному, так і світовому освітньому просторі.

\section{СПИСОК ВИКОРИСТАНИХ ДЖЕРЕЛ ТА ЛІТЕРАТУРИ}

1. Ганаба С. О. "Навчати мисленню" : епістемологічний проект Метью Ліпмана [Електронний ресурс]/ С. О. Ганаба. - Режим доступу : http://irbis-nbuv.gov.ua/cgi-bin/irbis_nbuv/cgiirbis_64.exe.

2. Сухомлинський В. О. "Я розповім вам казку... Філософія для дітей" / Василь Сухомлинський ; уклад. Сухомлинська О. В. - Х. : ВД "ШКОЛА", 2016. - 576 с.

3. Сухомлинська О. В. "Філософія для дітей в етичній спадщині В. О. Сухомлинського" / О. В. Сухомлинська // В. О. Сухомлинський у роздумах сучасних українських педагогів: [монографія] / упоряд. О. В. Сухомлинська, О. Я. Савченко ; авт. кол. : О. В. Сухомлинська, О. Я. Савченко, В. С. Курило, І. Д. Бех та ін. - Луганськ : Вид-во ДЗ "ЛНУ імені Тараса Шевченка", 2012. - С. 52-64.

4. Сухомлинська О. В. В. О. Сухомлинський і моральне виховання : трансформація педагогічних цінностей / О. В. Сухомлинська // В. О. Сухомлинський у роздумах сучасних українських педагогів : [монографія] / упоряд. О. В. Сухомлинська, О. Я. Савченко ; авт. кол. : О. В. Сухомлинська, О. Я. Савченко, В. С. Курило, І. Д. Бех та ін. - Луганськ : Вид-во ДЗ "ЛНУ імені Тараса Шевченка", 2012. - С. 64-73.

5. Адаменко Н. "Спільнота дослідників" М. Ліпмана : філософські запитування обговорення, аргументації та контраргументації вустами дітей" / Надія Адаменко // Філософія освіти. - 2011. - № 1-2 (10). - С. $42-45$. 
6. Пікуль Л. В. "Уроки мислення" В. Сухомлинського і "Філософія для дітей" Метью Ліпмана / Л. В. Пікуль // Постметодика. - 2013. - № 6 (115). - С. 22-24.

7. Сухомлинська О. В. "Філософія для дітей як педагогічна проблема" / О. В. Сухомлинська // Психологопедагогічні проблеми сільської школи. - 2002. - С. 8-19.

8. Юлина Н. С. "Философия для детей" / Н. С. Юлина // Вопросы философии. - 1993. - № 9. - С. 151-158.

\section{REFERENCES (TRANSLATED \& TRANSLITERATED)}

1. Hanaba S. O. "Navchaty myslenniu" : epistemolohichnyi proekt Met'yu Lipmana ["Teaching Thought": Matthew Lipman's Epistemological Project] [Elektronnyi resurs ] / S. O. Hanaba. - Rezhym dostupu : http://irbisnbuv.gov.ua/cgi-bin/irbis_nbuv/cgiirbis_64.exe.

2. Sukhomlyns'kyi V. O. "Ya rozpovim vam kazku... Filosofiia dlia ditei" ["I Will Tell you a Fairy Tale ... Philosophy for Children"] / Vasyl' Sukhomlyns'kyy ; uklad. Sukhomlyns'ka O. V. - Kh. : VD "ShKOLA", 2016. - 576 s.

3. Sukhomlyns'ka O. V. V. O. Sukhomlyns'kyy i moral'ne vykhovannya : transformatsiia pedahohichnykh tsinnostei [V. O. Sukhomlinsky and Moral Education: the Transformation of Pedagogical Values] / O. V. Sukhomlyns'ka // V. O. Sukhomlyns'kyi u rozdumakh suchasnykh ukrayins'kykh pedahohiv : [monohrafiia]/ uporyad. O. V. Sukhomlyns'ka, O. Ya. Savchenko ; avt. kol. : O. V. Sukhomlyns'ka, O. Ya. Savchenko, V. S. Kurylo, I. D. Bekh ta in. - Luhans'k : Vyd-vo DZ "LNU imeni Tarasa Shevchenka", 2012. - S. 64-73.

4. Sukhomlyns'ka O. V. "Filosofiia dlia ditei v etychnii spadshchyni V. O. Sukhomlyns'koho" ["Philosophy for Children in the Ethical Inheritance of V. O. Sukhomlynsky"] / O. V. Sukhomlyns'ka // V. O. Sukhomlyns'kyy u rozdumakh suchasnykh ukrayins'kykh pedahohiv : [monohrafiia] / uporiad. O. V. Sukhomlyns'ka, O. Ya. Savchenko ; avt. kol. : O. V. Sukhomlyns'ka, O. Ya. Savchenko, V. S. Kurylo, I. D. Bekh ta in. - Luhans'k : Vyd-vo DZ "LNU imeni Tarasa Shevchenka", 2012. - S. 52-64.

5. Adamenko N. "Spil'nota doslidnykiv" M. Lipmana : filosofs'ki zapytuvannia obhovorennia, arhumentatsii ta kontrarhumentatsii vustamy ditei" ["Community of Researchers" of M. Lipman: Philosophical Questions for Discussion, Argumentation and Counter-Argumentation by the Children's mouth"] / Nadiia Adamenko // Filosofiia osvity [Philosophy of Education]. - 2011. - № 1-2 (10). - S. 42-45.

6. Pikul' L. V. "Uroky myslennia" V. Sukhomlyns'koho i "Filosofiia dlia ditei" Met'yu Lipmana. ["Lessons of Thinking" by V. Sukhomlynsky and "Philosophy for Children" by Matthew Lipman"] / L. V. Pikul // Postmetodyka [Postmethodology]. - 2013. - № 6 (115). - S. 22-24.

7. Sukhomlyns'ka O.V. "Filosofiia dlia ditei yak pedahohichna problema" ["Philosophy for Children as a Pedagogical Problem"] / O. V. Sukhomlyns'ka // Psykholoho-pedahohichni problemy sil's'koi shkoly [Psychological and Pedagogical Problems of a Rural School]. - 2002. - S. 8-19.

8. Yulina N. S. "Filosofiia dlia detei" ["Philosophy for Children"] / N. S. Yulina // Voprosy Filosofii [Philosophy Issues]. - 1993. - № 9. - S. 151-158.

\section{Белан А. В. Философия для детей В. А. Сухомлинского в мировом образовательном пространстве.}

В статье рассматривается философия для детей В. А. Сухомлинского как составляющая моральноэтического воспитания личности, обосновано приоритетность значения развития мышления ребенка, формирования его мировоззрения через призму философского знания посредством художественного слова в процессе диалогического взаимодействия с педагогом. На основе научного и литературного

наследия В. А. Сухомлинского показано его новаторство в проблеме развития духовности и интеллектуального потенциала личности, установлена взаимосвязь взглядов педагога с подобньми

идеями М. Липмана (США), охарактеризовань особенности внедрения философии для детей в отечественное и мировое образовательное пространство.

Ключевые слова: философия для детей, мышление, духовность, гуманизм, личность, литература для детей, образовательное пространство.

\section{Belan H. V. Philosophy for Children of V. O. Sukhomlynsky in the World Educational Space.}

In the article the philosophy for children as a part of $V$. O. Suhomlynsky's moral and ethical concept of the individual education is revealed, it is grounded the priority of it's value to the development of the child's thinking, forming its outlook in the light of philosophical knowledge by means of artistic expression in the process of dialogic interaction with the teacher. Based on the scientific and literary heritage of

$V$. O. Suhomlynsky, his innovation is shown in the issue of spiritual and intellectual potential of the individual, the relationship of the pedagogue's ideas is set with similar ideas of M. Lipman (USA), it is described the features of the introduction of philosophy for children in domestic and international educational space. It is noted the semantic relationship of the Ukrainian and American views of teachers on child's knowledge of the world through the prism of philosophical knowledge. In the article is generalized the concept of teaching children with philosophy of M. Lipman and V. O. Suhomlynsky. They singled out the following elements: texts for children's reading, which lies in a latent or apparent form of one or more philosophical issues; educational and methodical literature for teachers, which outlines the methodology of the teacher's work with these texts; generalized theoretical works, which analyze the experience, achievements and flaws in the teaching of 
philosophy at school; Socratic dialogue between teacher and student as a direct learning method. It is emphasized the importance of innovation and educational research of $V$. O. Suhomlynsky on moral education of the individual, the development of thinking, feelings, values and introducing the basics of philosophical knowledge in practice of educational activities in school. It is proved that the idea of the pedagogue have been and remain a catalyst for scientific discovery and priceless heritage of teaching science that led to the formation of conceptual changes in its development both in the domestic and world educational space.

Key words: philosophy for children, thinking, spirituality, humanism, personality, literature for children, educational space. 